\title{
Millennials Behavioral Intention in Using Mobile Banking: Integrating Perceived Risk and Trust into TAM (A Survey in Jawa Barat)
}

\begin{abstract}
Suresh Kumar, ${ }^{1 *}$ Angela Leonie Keyko Yukita ${ }^{1}$
${ }^{1}$ Faculty of Business - President University, Indonesia sureshkumar@president.ac.id

ABSTRACT

To analyze the major factors influencing user acceptance in using mobile banking, this current study integrates the Technology Acceptance Model (TAM) model with risk (privacy, financial, security, and time risk), trust, and attitude constructs. This research employed a quantitative approach through an online survey and distributed it through Line, Twitter, WhatsApp, and Instagram. The questionnaire consisted of 46 questions and 400 valid responses received. Structural Equation Modeling (SEM) was applied to examine the prescient behavior of the proposed components of the research model. All constructs passed the validity and reliability test. Results reveal that risk influences usefulness and ease of use impacts on usefulness. Furthermore, usefulness influences attitude, and usefulness and attitude influence the intention to use mobile banking. Surprisingly, it is found that trust did not influence attitude, and trust and ease of use did not impact on the usage intention mobile banking. Mobile banking related issues are yet to be examined empirically in millennials users, especially in West Java. This research was developed by extending the TAM model with perceived risk with 4 sub-dimensions and trust to reveal the need of acquring mobile banking.
\end{abstract}

Keywords: mobile banking, TAM, perceived risk, trust, attitude, intention.

\section{INTRODUCTION}

Banking industries continue to grow and experience changes over time, adjusting the needs of the society that continues to keep on evolving [1]. Originally, a bank is just a place where people put their money to prevent criminality, a $\mathrm{p}$ lace to deposit for future use. Nowadays banks can be a place of investment and provide a lot of convenience for their users and always receive positive responses from them [2]. Digital banking has advanced across the region in different markets at different paces, especially in developed markets such as Australia, which is leading the world in online banking where banks in the country are the fast mobile banking (m-banking) adopters and consistently built user-friendly mobile banking applications to fit their customers ' digital needs [3]. Based on the study which has been done in 15 countries in Asia to 17,000 people, Indonesia is the fastest country to carry out digital adoption [4]. Since 2014, Indonesia has experienced a significant growth in the use of digital banking which contributes up to $32 \%$ to the bank population [5]. This was marked by the emergence of digital banking products, starting from mobile banking, internet banking, electronic money, cashless transactions through QR codes, biometric-based transactions, and blockchain-based transactions [6].

As there are many transactions of mobile banking, there are also more cases related to the service which can result in lo wer levels of customer confidence in banks or digital banking providers [7]. Even though the number of users of mobile banking keeps on increasing, but $32 \%$ of mob ile users in Indonesia mention that the major problem in using mobile banking for financial transactions is a matter of trust [8]. Many facilities provided through mobile banking also make the users lack confidence in the ease of use, as whenever hackers can retrieve information about user accounts and can take away their balance [9]. The most recent case is when there are some users said that they had difficulty in making transactions through mobile banking owned by the largest private bank in the country [10]. It is stated by Otoritas Jasa Keuangan (OJK) that there are up to 1305 complaints of technology-based financial services which most of the complaints received are from mobile banking platforms due to transfer errors, system downs, and debit errors [11].

As the result, the level of acceptance regarding mobile banking can be decreased if major banks in 
Indonesia do not start solving the problems that have occurred. This is in addition to the fact that the main factors that form the intention of using m-banking are considerably required [12]. It has to be noted that because of the high growth in m-banking as mentioned before, factors affecting intention in adopting m-banking need to be strongly understood [13] especially by incorporating not only Technology Acceptance Model (TAM) but also attitude, trust, and perceived risk [14].

Therefore, the aims in doing this study are: To examine the impact of risk towards usefulness, to appraise the relationship between usefulness, attitude and intention, for testing the relationship of ease of use between attitude and usefulness, to examine the influence between trust, attitude and usefulness, and to test the influence of attitude towards intention. This study is systematically designed as follows: the second part elaborates hypothesis development and research gap, the third part focuses on method as for the data collection and analysis, sampling technique, and instruments, and the last part discusses the results, conclusions, and limitations for the future research.

\section{HYPOTHESIS DEVELOPMENT}

\subsection{Relationship among variables}

The result from [15] study about m-banking applications in Pakistan shows that risk still can be prevented or minimized to increase the degree of usefulness in adopting the applications. However, to know the attitude of users regarding perceived risk, it will be evaluated through PU and PEOU. On the contrary, it is a different situation in Yemen where [16] it was found that when someone thinks that the risk is high while using $\mathrm{m}$ banking, it will be automatically weakened the usefulness of the applications. Hence, this study proposes:

\section{H1. Risk influences perceived usefulness}

A study about social networking med ia in Libya shows if someone feels that social media is straightforward and easy to utilize, the intention to use occurs [17]. According to the authors, the usage of technology becomes useful when it is determined by PEOU. Hence, technology like m-banking that convenient to use will create the best advantage or cost proportion for the achievement-oriented people [15]. The same issue in Jordan, it needs an easy and less effort technology to make the customers perceive to use m-banking application so it will be mo re useful to do transactions in their daily life [18].

Another thing about the founding of PEOU since $\mathrm{m}$ banking is known as a user-friendly application and to use it, it's only required very basic skills, then the users are having the attitude to embrace m-banking services [15]. In online learning contexts in China, PEOU is vital for PU and attitudes towards using e-learning [19]. One possible explanation for this outcome may be, that each e-learning is accessible via different platforms, which makes e-learning easy to use; thus, these allow students to have a complete attitude depends on the PU of the system. Hence, the hypotheses are proposed as:

H2. Ease of use influences usefulness

H3. Ease of use influences attitude

A previous study which was conducted in Saudi Arabia provides strong evidence where users of m-banking are tended to build a decisive perception and intention in adopting m-banking technology due to its ability, benevolence, and integrity [12]. According to [18], increasing the level of Jordanian users' trust, not just enhances the customers' ability to embrace such a system, yet additionally reinforces the positive view of the usefulness of using m-banking.

Trust is an important variable towards attitude because if the outcomes indicate an increase in trust in one unit, it is strange for a respondent who has high intention in adopting mobile banking to go up by multiple times from that amount [20]. In an online group buying of Malaysia, a favorable opinion of a reputation from vendors leads clients to take a positive view of the attitude and trust of an online supplier [21]. Therefore, the following hypotheses are developed:

H4. Trust influences perceived usefulness

H5. Trust influences attitude

In 2017, Sharma has proven that the people of Oman is likely to have a low maturity level in using m-banking, but because of this issue, an individual who has been using m-banking feels that the application gives advantages and helps a lot in accomplishing many kinds of tasks which are related to finance. It is also believed that in Indonesia, customers with a perceived mo re positive PU will have a better attitude and decision to shop online in online shopping [22].

In the context of internet banking, transactions such as online payments, transfer, or request for checking which those are saving users' time and increasing the effectiveness of the technology are considered useful.

[23]. Moreover, these benefits are seen to be useful, so it is more likely for users to have intention in using internet banking. A study by [24] in Korea, found out that by using mobile devices that give different realtime information and more attractive communication between users, those benefits are helping for the behavioral intention in using mobile devices increase. Based on the review, this study hypothesizes the sixth and seventh:

H6. Perceived usefulness influences attitude

H7. Perceived usefulness influences behavioral intention

According to [15] attitude is the basic and necessary factor in influencing behavioral intention. Customers 
who are having a decisive attitude on m-banking would plan to adopt it. As well as [25] study, to determine the intention in using and adopting technology, an individual will ultimately need the key precursor which is attitude. From both of the researches, it can be concluded that attitude is one of the crucial roles in influencing the using technology. Consequently, the following hypothesis is formulated:

H8. Attitude influences behavioral intention

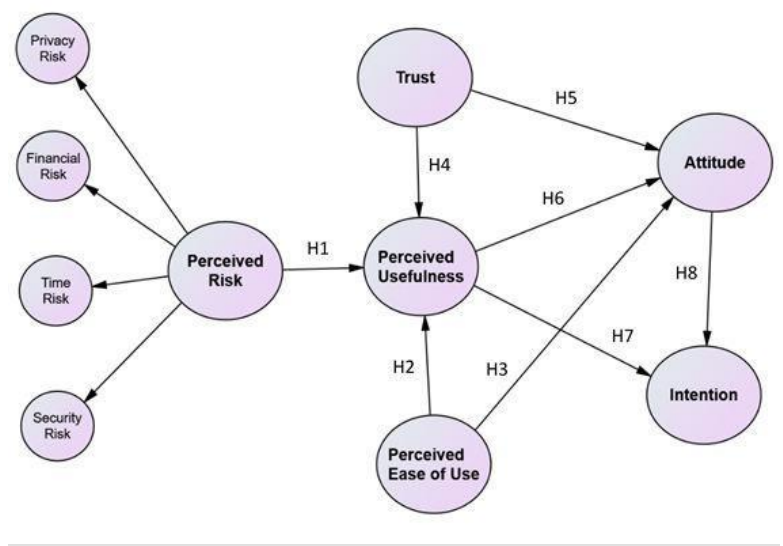

Figure 1. Theoretical Framework

\subsection{Research Gap}

According to the inventor of TAM, Davis, TAM has been conveyed amongst the theoretical frameworks to legitimize how clients utilize as well as assent to an innovation [26]. Several previous studies have been using this model for exploring the aspects of new technology that are affecting an individual. [25] had conducted a study about the usage intention of $\mathrm{m}$ banking applications with TAM framework and add the extending variables such as trust, risk, and social image. Other studies by [27], conducted research using TAM to investigate the intention to use m-banking with awareness, perceived risk, resistance, and compatibility adoption. In the same year, a study about mobile payments was conducted by extending TAM with several variables, such as self-efficacy, privacy, and technology anxiety [28]. Therefore, in this study, the behavioral intention in using $\mathrm{m}$-banking is extended TAM by trust and perceived risk with its subdimensions for instance, time, financial, security, and privacy risk.

There are few studies about the diffusion of innovation theory and technology acceptance model. A previous study by [29] only focused on compatibility, relative advantage, and complexity towards perceived usefulness, perceived ease of use, attitude, behavior intention of use, and actual use. According to [29], the topic of the study is a financial technology (Fintech) and was conducted in Taiwan. A previous study by [30] only focused on relative advantage, compatibility, complexity, observability, and social influence towards PU, PEU, attitude, and future usage intention, also discuss insights from DOI and TAM and the topic is about Uber mobile application and conduct on the USA.

A previous study by [31], used the same variable in this study to reveal the drivers of students' intention to study through online system, whereas this study investigates the influence of TAM and perceived risk using m-banking. The previous study was conducted in Malaysia whereas this study is conducted in Indonesia especially in Jawa Barat and also the industry being discussed is different for both [31].

\section{METHODS}

This study applied a quantitative research approach and conducted in Jawa Barat home to the largest internet usage [32] and the biggest number of millennials [33] in Indonesia. The millennials had to be mobile banking users to be selected as respondents. A survey method with a questionnaire form, distributed through Twitter, Line, WhatsApp, and Instagram, to capture the perception of respondents was used and managed to collect 400 respondents, adequate for a big population

[34] with purposive sampling technique. The questionnaire was divided into three sections. Section A comprised 3 screening questions to know whether

respondents are eligible to continue to be in the survey or not. Section B contained the respondents' characteristics (age, employment status, gender, and frequency of using $\mathrm{m}$ banking). Section $\mathrm{C}$, the last part of the questionnaire, comprised of 46 questions on the aspects related to mobile banking. For perceived risk, item statements were adapted fro $\mathrm{m}$ [16] and [35] and further, it was breakdown into four dimensions: security (5 items), privacy (4 items), time (4 items), financial (5 items). Items statements for trust contains 7 items which were adapted from [12], [34], [18]. Six items statement of perceived usefulness were adapted from [23], [36]. Studies by [34] and [25] were used to make ease of use items (6 items). For attitude (5 items) and behavioral intention (4 items), item statements were adapted from [13], [37]. The items were designed with a 7-point Likert scale (absolutely disagree until absolutely agree).

To analyze the data, steps taken were normality test, common method bias test, convergence and discriminant validity, and composite reliability test, model fit, hypothesis, and r-square test. Normality is a process of testing the data to assess the distribution of data among variables, whether or not the data is normally distributed [38] with the criteria skewness kurtosis in the range of $\mathbf{- 1 . 9 6} \leq \mathbf{t} \leq \mathbf{1 . 9 6}$ [39]. The common method bias (CMB) occurs when the relationships between two or more constructs are biased due to the method of measuring the data is same [40]. If that happens, not only will it risk the construct validity and blur the relationships between two or mo re constructs, it will also affect the testing results of the 
hypothesis and ruin the quality [41]. If the total or overall variance is $<50 \%$ for a single factor, it imp lies that CMB will not affect the data, hence the results [41]. Construct validity is a test that inquires how far the item statements can measure what is intended to be measured per a conceptual definition that has been set [42]. Convergent validity defines as the degree to which a test measures the same as other tests that are expected to measure the construct and the criteria used is average extracted variance $(\mathrm{A} \mathrm{VE})>0.5$ [42]. To determine discriminant validity, the variances between constructs are compared with the square root (SQRT) of A VE for each construct in the relevant columns and rows [43]. Reliability is the level of a measurement instrument that gives constant results each time it is used, with an assumption that the basic or fundamental thing being measured does not change [42]. In this study, the statistical tool that is used is composite reliability (CR) with the criteria $\alpha$ is greater than 0.70 [42]

Before conducting a hypothesis testing in structural equation modeling, the first step is always to check on its model fit with the criteria CM IN/DF is less than 5, goodness of fit (GFI), adjusted goodness of fit (A GFI), comparative fit index (CFI), the incremental fit index (IFI), and Tucker Lewis Index (TLI), and finally is the root mean square error (RMSEA) which has to be less than 0.08 [44]. For hypothesis testing, the criteria used is the significance level (p-value) with a value is less than 0.05 which means the probability of evidence against the null hypothesis is less than $5 \%$. In this case, it is time to reject the null hypothesis and the alternative can be accepted [45]. The strength of the model is measured through r-square, how far the extension of one variable explains the variance of the second variable [45].

\section{RESULT AND DISCUSSION}

The vast majority of the respondents (Table 1) are female, accounting for $51.3 \%$. All of the respondents are of their millennial age with the most total of $70 \%$ are $19-26$ years old. Moreover, $54.5 \%$ of respondents are students, followed by a full-time worker with $19,3 \%$. With a percentage of $63.5 \%$, the participants are having monthly income less than IDR 5.000.000, 32.3\% get IDR 5.000.001 - IDR 10.000 .000 and $4.3 \%$ get mo re than IDR 10.000.001. Most of the respondents are using m-banking in their daily life $(60 \%)$, at least once a day $(15 \%)$, and more than once a day (13\%).

In testing the skewness -kurtosis for normality test, this study used AMOS 24 and the result is the data are normally $d$ istributed where the value of skewness kurtosis was in the range of $\mathbf{- 1 . 9 6} \leq \mathbf{t} \leq \mathbf{1 . 9 6}$. The value of total variance for all variables was $22 \%$ wh ich is less than the minimu $\mathrm{m}$ standard $(50 \%)$, hence, the relationship between data that have been analysed does not diverge.
Table 1. Respondents' Profile

\begin{tabular}{|c|c|c|c|}
\hline \multirow{2}{*}{ Variables } & \multirow{2}{*}{ Items } & \multicolumn{2}{|c|}{ Respondents } \\
\hline & & Frequency & $\%$ \\
\hline \multirow{2}{*}{ Gender } & Female & 205 & $51.30 \%$ \\
\hline & Male & 195 & $48.80 \%$ \\
\hline \multirow{3}{*}{ Age } & $19-26$ & 280 & $70.00 \%$ \\
\hline & $26-33$ & 103 & $25.80 \%$ \\
\hline & $33-39$ & 17 & $4.30 \%$ \\
\hline \multirow{6}{*}{$\begin{array}{l}\text { Employment } \\
\text { Status }\end{array}$} & Unemployed & 0 & $0.00 \%$ \\
\hline & Student & 218 & $54.50 \%$ \\
\hline & Casual & 36 & $9.00 \%$ \\
\hline & Part Time & 29 & $7.30 \%$ \\
\hline & Full Time & 77 & $19.30 \%$ \\
\hline & Self-employed & 40 & $10.00 \%$ \\
\hline \multirow{3}{*}{$\begin{array}{l}\text { Monthly } \\
\text { Income }\end{array}$} & <IDR 5.000.000 & 254 & $63.50 \%$ \\
\hline & IDR 5.000.001 - IDR 10.000 .000 & 129 & $32.30 \%$ \\
\hline & >IDR 10.000 .001 & 17 & $4.30 \%$ \\
\hline \multirow{6}{*}{$\begin{array}{l}\text { Frequency in } \\
\text { using m- } \\
\text { banking }\end{array}$} & Everyday & 240 & $60.00 \%$ \\
\hline & More than once a day & 52 & $13.00 \%$ \\
\hline & Once a day & 60 & $15.00 \%$ \\
\hline & 1 - 2 times a week & 12 & $3.00 \%$ \\
\hline & 3 - 5 times a week & 36 & $9.00 \%$ \\
\hline & Less than once a month & 0 & $0.00 \%$ \\
\hline
\end{tabular}

Table 2. Validity and Reliability results

\begin{tabular}{|c|c|c|c|}
\hline \multirow{2}{*}{ Variable } & $\begin{array}{c}\text { Average } \\
\text { Variance }\end{array}$ & $\begin{array}{c}\text { Composite } \\
\text { Reliability }\end{array}$ & $\begin{array}{c}\text { Cronbach' } \\
\text { s Alpha } \\
(\mathbf{C R})\end{array}$ \\
& $\begin{array}{c}\text { Extracted } \\
(\mathbf{C V E})\end{array}$ & \\
\hline PerRisk & 0.83 & 0.9 & 0.8 \\
\hline TRT & 0.56 & 0.77 & 0.78 \\
\hline PU & 0.84 & 0.85 & 0.85 \\
\hline PEOU & 0.58 & 0.76 & 0.76 \\
\hline ATT & 0.56 & 0.8 & 0.79 \\
\hline INT & 0.67 & 0.77 & 0.76 \\
\hline
\end{tabular}

The convergent validity (Table 2) of this study is confirmed through estimation of A VE (PerRisk $=0.83$; $\mathrm{TRT}=0.56 ; \mathrm{PU}=0.84 ; \mathrm{PEOU}=0.58 ; \mathrm{ATT}=0.56 ; \mathrm{INT}$ $=0.67$ ). For the discriminant valid ity, the root value of A VE for some constructs are greater from the correlation between constructs. However, for the trust ease of use, ease of use-attitude and attitude-intention construct, there are little disputes. It might be the impact of modification indices that has been done, hence a second order approach needs to be conducted for hypothesis testing [46]. The results for CR (Tab le 2) for each construct fulfill the requirements $(\geq 0.7)$ to be said as a reliab le data $($ PerRisk $=0.90 ;$ TRT $=0.77 ; \mathrm{PU}=0.85 ; \mathrm{PEOU}=0.76$; $\mathrm{ATT}=0.80 ; \mathrm{INT}=0.77$ ). 
After testing the model, it shows a good fit (CM IN/DF= 1.473; GFI $=0.872 ; \mathrm{A}$ GFI $=0.852$; $\mathrm{IFI}=919 ; \mathrm{CFI}=$ 0.918; TLI= 0.909; RMSEA $=0.034)$ and fulfil the requirement to conduct the hypothesis testing. The results of the hypothesis testing (Table 3) showed that PerRisk is has a significant influence toward PU $(\mathrm{CR}=$ 2.183; $\beta=0.22 ; p=0.029)$. Therefore, it can be concluded that Hypothesis 1 is accepted. This study showed a positive impact between PEOU and PU (CR = 6.293; $\beta=1.267 ; p=0.000)$. It shows that Hypothesis 2 is accepted. The study found that PEOU is negatively influence ATT towards m-banking $(\mathrm{CR}=0.348 ; \beta 078$; $\mathrm{p}=0.728)$. Hence, Hypothesis 3 is not supported.

The influence of TRT to PU in this research is unfortunately found insignificant $(\mathrm{CR}=-0.58 ; \beta=-156$; $\mathrm{p}=0.562)$. Th is means that Hypothesis 4 is rejected. The test gave an insignificant affect between TRT and ATT toward m-banking $(\mathrm{CR}=1.015 ; \beta=188 ; \mathrm{p}=$ 0.310 ). Therefore, Hypothesis 5 is rejected. The analysis of hypothesis for PU to ATT towards $\mathrm{m}$ - banking conclude that it is significantly influence each other (CR $=2.513 ; \beta=0.362 ; p=0.012$ ). It can be said that Hypothesis 6 is accepted. Further, PU was found impacting the INT in using $\mathrm{m}$-banking significantly (CR $=0.755 ; \beta=0.423 ; \mathrm{p}=0.001$ ).

This shows the acceptance of the Hypothesis 7. The relationship between ATT and INT of $\mathrm{m}$ - banking adoption was found significantly affected each other $(\mathrm{CR}=3.636 ; \beta=513 ; \mathrm{p}=0.001)$. Means that Hypothesis 8 is accepted. The model also shows a strong model with a strength of $60.8 \%$.

Table 3. Hypothesis results

\begin{tabular}{|c|c|c|c|c|c|c|}
\hline $\begin{array}{c}\text { Hypoth } \\
\text { esis }\end{array}$ & Statement & $\begin{array}{l}\text { Es } \\
\text { timate }\end{array}$ & S.E. & C.R. & $\mathrm{P}$ & $\begin{array}{l}\text { Conclus } \\
\text { ion }\end{array}$ \\
\hline $\mathrm{H} 1$ & $\begin{array}{l}\text { PerRisk } \rightarrow \\
\text { Usefulness }\end{array}$ & 0.22 & 0.101 & 2.183 & 0.029 & Accepted \\
\hline $\mathrm{H} 2$ & $\begin{array}{l}\text { EaseOfUse } \rightarrow \\
\text { Usefulness }\end{array}$ & $\begin{array}{l}1.26 \\
7\end{array}$ & 0.201 & 6.293 & 0.001 & Accepted \\
\hline $\mathrm{H} 3$ & $\begin{array}{l}\text { EaseOfUse } \rightarrow \\
\text { Attitude }\end{array}$ & 0.078 & 0.223 & 0.348 & 0.728 & Rejected \\
\hline H4 & $\begin{array}{l}\text { Trust } \rightarrow \\
\text { Usefulness }\end{array}$ & $\begin{array}{l}- \\
0.15 \\
6\end{array}$ & 0.268 & -0.58 & 0.562 & Rejected \\
\hline H5 & Trust $\rightarrow$ Attitude & 0.188 & 0.185 & 1.015 & 0.31 & Rejected \\
\hline H6 & $\begin{array}{l}\text { Usefulness } \rightarrow \\
\text { Attitude }\end{array}$ & $\begin{array}{l}0.36 \\
2\end{array}$ & 144 & .513 & 0.012 & Accepted \\
\hline $\mathrm{H} 7$ & $\begin{array}{l}\text { Usefulness } \rightarrow \\
\text { Intention }\end{array}$ & $\begin{array}{l}0.42 \\
3\end{array}$ & .089 & 4.755 & 0.001 & Accepted \\
\hline $\mathrm{H} 8$ & $\begin{array}{l}\text { Attitude } \rightarrow \\
\text { Intention }\end{array}$ & $\begin{array}{l}0.51 \\
3\end{array}$ & 0.141 & 3.636 & 0.001 & Accepted \\
\hline
\end{tabular}

Considering the relationship of perceived risk on perceived usefulness, the primer decision in adopting $\mathrm{m}$ banking was affected fundamentally by the usefulness of the system or application. This research has the same result with [47] study where perceived risk was significantly influence perceived usefulness. When implementing and designing a secure application, i.e. provides two-step verification every time users doing transactions.
The effect of risk can be reduced as this will imp rove the confidence of the user to use m-banking. The study found that PEOU positively affects PU of mbanking among millennial adopters, it is supported by

[48] study conducted in the United Arab Emirates. The study reveals that the more the m-banking is easy to use, the more time users save by using the application, including the easiness in operating the apps, thus it will improve performance and become generally useful. Furthermore, [49] stated that users do not need any special skills to be able to use m-banking because it has user-friendly features, therefore they are willing to utilize the system. Hence, a system that appears to be convenient and easy encourages its use.

This study shows a contradict result from the prediction of TAM where perceived ease of use was not significant to users' attitude toward m-banking. Th is happens regarding the characteristics of users which they only intend to adopt a system if they are convinced the system would be helpful [50]. Also, the result also consistent with the study by [51] which states that PEOU is insignificant to users' attitudes. The easiness of using m-banking did not make people change their attitude to m-banking easily and quickly. The fact that the respondents in this research are millennials generation, it might be with their extraordinary knowledge in technology enable them to quickly access m-banking regardless of their level of sophistication [52]

Turns out that trust has no relationship either to the attitude or perceived usefulness in this study. It is stated that users' trust was not influenced by the benefits which are given by m-banking. In other words, someone would not necessarily consider m-banking useful, despite trusting in m-banking. These results contrast with the previous study by [53]. Further, it was an interesting finding that trust had not influenced attitude towards m-banking, it is supported by [54] study. This is inconsistent with some prior research [14], [18], [55]. Since this research aims to study the adoption of $\mathrm{m}$ banking in West Java, Indonesia, the results might vary from a specific m-banking to another m-banking.

In this study, the PU of m-banking found to be significantly influenced the attitude towards it. Th is finding is consistent with existing TAM studies and also previous studies [14], [51], [55]. This imp lies that if the awareness of users in using m-banking increases i.e. quickly and safely transferring money, it will drive them in having the attitude to use the apps. The usefulness of m-banking in giving the users to pursue their bank transactions at any time and in any circumstances is the crucial factor affecting the attitude towards m-banking.

From the analysis, it is revealed that perceived usefulness highly effects on intention in m-banking usage. This result is supported by several studies [19], [26], [46], [50] which the authors claim that PU is the most important aspect until someone has the behavior to continue using m-banking. Imp roving users' belief in 
the effectiveness of m-banking can make them intend to use it continuously. It is also found by [37] that mbanking is beneficial for consumers and banks, as mbanking assists users to get facilities round the clock while banks get to minimize the infrastructure cost.

It is finally proven that attitude is significantly influenced the intention of millennials users in West Java to use mobile banking, which is led to an acceptance of H8. So me previous studies also support this significant result between attitude and intention to continue using it [13], [15], [23]. Considering that attitude is the fundamental factor to influence the intention, ultimately, those with decisive attitude intend to utilize m-banking. To be underlined that attitude plays a significant role in influencing the use of a technology [56].

\section{CONCLUSION}

In the nutshell, it can be concluded that 5 of 8 hypotheses in this study were having a significant relationship with each other. The hypotheses are Perceived risk influences perceived usefulness, perceived ease of use influences perceived usefulness, perceived ease of use did not influence attitude for users in using m-banking, Trust did not influence perceived usefulness, Trust did not influence attitude towards mbanking, perceived usefulness influences attitude, perceived usefulness influences intention in using $\mathrm{m}$ banking, Attitude influence intention in using mbanking.

The research significantly extends Jawa Barat literature on the information system in terms of latent technologies such as mobile banking, which need to be further assessed. This study attempts to fill the gap by ensuring its adoption and continuing usage. TAM properly acknowledges the statistical perspectives of the empirical results with the external variables of perceived risk, trust, and attitude to forecast the customers' adoption and continuity intention.

In developing the usage of mobile banking, this current study has several implications. Considering the increasing number of m-banking users in Indonesia, it is very important to ensure that they will continue to keep using the system. To achieve this goal, attention is required so the design of the m-banking application is useful, easy to use, and trustworthy systems. Banks can make campaigns to exp lain the advantages of using the apps, so users see the usefulness of m-banking and increase their intention to use it through attitude. To overcome the resistance of customers and the perceived risk in new technologies, it can also be done by educating the consumers about the apps and also the benefits. It is better to include users in experiencing $\mathrm{m}$ banking with dummy apps before making their actual transactions. This experience could instantly minimize the perceived risk by consumers.
This study helps bank managers focus on building trust to promote and increase mobile banking use. To enhance trust, banks need to adopt technology from the third party security system. The managers also should pay more attention and maintain the features in the apps so are still easy and friendly to use. This study revealed that users of mobile banking are dominated by millennials age, it can be an added advantage for the manager to build a relationship with merchants such as giving promo or discount if customers use their brand m-banking because the average purchasing power of millennials has surpassed other demographic groups.

There are some limitations in this study which in future researches need to be addressed. Perceived risk and trust are the extensions of TAM for this study, but it is better to add other factors such as awareness, eWOM, task technology fit [44], [57], [58] so it will be easier to understand and be more accurate in predicting the intention to adopt m-banking. This study is only focusing on the users of m-banking who their millennials age, therefore future studies can target other m-banking users of different ages. Last, this study had excluded other digital banking services such as internet banking. SMS banking, and phone banking. Since these services may result from different risks, hence it is worth to do a study with other digital banking services to understand perceived risks and other constructs.

\section{AUTHORS' CONTRIBUTIONS}

The first author developed the theoretical formalism and the second author did the survey. Further, the analysis of the data gathered from the survey was conducted by the first author while the second author wrote the manuscript under the guidance of the first author. The final manuscript was then edited by the first author.

\section{REFERENCES}

[1] Fransisca, "Perkembangan Digital Banking dan Peluangnya di Indonesia,” 2019.

[2] B. Danamon, "Hari Bank Dunia, Lihat Perjalanan Layanan Perbankan di Era Digital,” 2019.

[3] A. G. Tarzimanov, Eugene; Herrero, "M obile banking seen to overtake internet banking," The Asian Banker, 2017.

[4] G. Yudistira, "Riset M cKinsey: Adopsi digital banking di Indonesia tercepat di Asia," kontan.co.id, 2019.

[5] Y. Ananta, "Riset: Pengguna M obile Banking Lebih Boros Tetapi Loyal," CNBC Indonesia, 2019.

[6] Apriyani, "Tantangan Perbankan Digital Era M ilenial," infobanknews, 2019.

[7] T. A. P. Ekadhani, "The Existence of Bank Indonesia Regulations: Analysis of the Protection for Financial Stability in Running Electronic Banking Activities in Indonesia,” pp. 2-3, 2019. 
[8] A. Kamirrudin, "M EF: Penggunaan M obile Banking Capai $80 \%$ di Indonesia, Isu Kepercayaan Menjadi Masalah Terbesar," DailySocial, 2016.

[9] M . A. Kartikawati, "Pengaruh Persepsi Risiko, Persepsi Kemudahan Penggunaan, Keuntungan Relatif Dan Kesesuaian Terhadap Adopsi M obile Banking Bank Bri Di Surabaya," Perbanas, pp. 4-5, 2017.

[10] A. D. Budiawati, "NoAkses M obile Banking BCA Sempat Bermasalah, Inikah Penyebabnya," dream, 2019. .

[11] G. Hartomo, "1.305 Pengaduan Keuangan di Februari, Kasus M obile Banking M endominasi,” oke finance, 2017.

[12] A. A. Alalwan, A. M . Baabdullah, N. P. Rana, K Tamilmani, and Y. K. Dwivedi, "Examining adoption of mobile internet in Saudi Arabia: Extending TAM with perceived enjoyment, innovativeness and trust," Technol. Soc., vol. 55, pp. 100-110, 2018, doi: 10.1016/j.techsoc.2018.06.007.

[13] G. Changchun, M . J. Haider, and T. Akram, "Investigation of the Effects of Task Technology Fit, Attitude and Trust on Intention to Adopt $\mathrm{M}$ obile Banking: Placing the M ediating Role of Trialability," Int. Bus. Res., vol. 10, no. 4, p. 77, 2017, doi: 10.5539/ibr.v10n4p77.

[14] S. Chauhan, "Acceptance of mobile money by poor citizens of India: Integrating trust into the technology acceptance model," Info, vol. 17, no. 3, pp. 58-68, 2016, doi: 10.1108/info-02-2015-0018.

[15] S. A. Raza, A. Umer, and N. Shah, "New determinants of ease of use and perceived usefulness for mobile banking adoption," Int. J. Electron. Cust. Relatsh. Manag., vol. 11, no. 1, p. 44, 2017, doi: 10.1504/IJECRM .2017.086751.

[16] O. Isaac, A. M . M utahar, N. M . Daud, T. Ramayah, and A. H. Aldholay, "The effect of awareness and perceived risk on the technology acceptance model (TAM ): mobile banking in Yemen," Int. J. Serv. Stand., vol. 12 , no. 2 , p. 180,2018 , doi: 10.1504/ijss.2018.10012980.

[17] A. M . Elkaseh, K. W. Wong, and C. C. Fung, "Perceived Ease of Use and Perceived Usefulness of Social M edia for e-Learning in Libyan Higher

Education: A Structural Equation $\mathrm{M}$ odeling Analysis," Int. J. Inf. Educ. Technol., vol. 6, no. 3, pp. 192-199, 2016, doi: 10.7763/ijiet.2016.v6.683.

[18] A. C. Simintiras, A. A. Alalwan, Y. K. Dwivedi, and N. P. Rana, "Influence of Perceived Usefulness, Trust and Self-Efficacy on Consumers ' Adoption of Telebanking : Insights from Jordan Introduction," Int. J. Bank Mark. Vol. 34 Iss 5 pp.Vol. 34 Iss 5 pp., vol. 34, no. 5, 2016.

[19] B. Wu and X. Chen, "Continuance intention to use M OOCs: Integrating the technology acceptance model (TAM ) and task technology fit (TTF) model," Comput. Human Behav., vol. 67, pp. 221-232, 2017, doi: 10.1016/j.chb.2016.10.028.

[20] H. J. Deepak Chawla, "Consumer perspectives about mobile banking adoption in India - a cluster analysis," Int. J. Bank Mark., vol. 34, no. 4, pp. 616636, 2017, doi: https://doi.org/10.1108/IJBM -032016-0037.

[21] N. M ohd Suki and N. M ohd Suki, "M odeling the determinants of consumers' attitudes toward online group buying: Do risks and trusts matters?," J. Retail. Consum. Serv., vol. 36, no. January, pp. 180-188, 2017, doi: 10.1016/j.jretconser.2017.02.002.

[22] D. Suleman, I. Zuniarti, and Sabil, "Consumer Decisions toward Fashion Product Shopping in

Indonesia: The effects of Attitude, Perception of Ease of Use, Usefulness, and Trust," Manag. Dyn. Knowl. Econ., vol. Vol.7, no. no.2, p. pp.133-146;, 2019, doi: DOI 10.25019/M DKE/7.2.01.

[23] S. Rahi, M . A. Ghani, and F. M . I. Alnaser, "Predicting customer's intentions to use internet banking: The role of technology acceptance model (TAM ) in e-banking," Manag. Sci. Lett., vol. 7, no. 11, pp. 513-524, 2017, doi: 10.5267/j.msl.2017.8.004.

[24] D. H. Yoo, D. S. Ko, and I. S. Yeo, "Effect of user's trust in usefulness, attitude and intention for mobile sports content services," J. Phys. Educ. Sport, vol. 17, no. 1, pp. 92-96, 2017, doi: 10.7752/jpes.2017.s1014.

[25] F. M uñoz-Leiva, S. Climent-Climent, and F. Liébana-Cabanillas, "Determinantes de la intención de uso de las aplicaciones de banca para móviles: una extensión del modelo TAM clásico," Spanish J. Mark. - ESIC, vol. 21, no. 1, pp. 25-38, 2017, doi: 10.1016/j.sjme.2016.12.001

[26] S. A. O. Bahaj, K. S. Aljaaidi, and T. M . Ahmed, "Using tam model to empirically examine students' attitudes towards e-services in college of business administration," Manag. Sci. Lett., vol. 9, no. 5, pp. 651-660, 2019, doi: 10.5267/j.msl.2019.2.006.

[27] R. Ali, Z. Jin, K. Wu, and T. C. M elewar, "How Does Reputation Win Trust? A Customer-Based M ediation Analysis," Int. Stud. Manag. Organ., vol. 47, no. 3, pp. 220-239, 2017, doi: 10.1080/00208825.2017.1318017.

[28] A. A. Bailey, I. Pentina, A. S. M ishra, and M . S. Ben M imoun, "M obile payments adoption by US consumers: an extended TAM ," Int. J. Retail Distrib. Manag., vol. 45 , no. 6, pp. 626-640, 2017, doi: 10.1108/IJRDM -08-2016-0144.

[29] A. T. F. Lou and E. Y. Li, "Integrating innovation diffusion theory and the technology acceptance model: The adoption of blockchain technology from business managers' perspective," Proc. Int. Conf. Electron. Bus., vol. 2017-Decem, pp. 299-302, 2017.

[30] S. M in, K. K. F. So, and M . Jeong, "Consumer adoption of the Uber mobile application: Insights

from diffusion of innovation theory and technology acceptance model," J. Travel Tour. Mark., vol. 36, no. 7, pp. 770-783, 2019, doi: 10.1080/10548408.2018.1507866.

[31] W. M . Al-Rahmi et al., "Integrating Technology Acceptance M odel with Innovation Diffusion Theory: An Empirical Investigation on Students' Intention to Use E-Learning Systems," IEEE Access, vol. 7, pp.

26797-26809, 2019, doi:

10.1109/ACCESS.2019.2899368. 
[32] APJII, "Penetrasi \& Profil Perilaku Pengguna Internet Indonesia," Apjii, p. 51, 2017.

[33] I. Budiati et al., "Profil Generasi M ilenial Indonesia," 2018.

[34] D. M ehrad and S. M ohammadi, "Word of M outh impact on the adoption of mobile banking in Iran," Telemat. Informatics, vol. 34, no. 7, pp. 1351-1363, 2017, doi: 10.1016/j.tele.2016.08.009.

[35] I. Arif, S. Afshan, and A. Sharif, "Resistance to Adopt M[48] obile Banking in a Developing Country: Evidence from M odified TAM ," J. Financ. Econ. Res., vol. 1, no. 1, pp. 25-42, 2016, doi:

$10.20547 /$ jfer 1601104 .

E. L. Slade, Y. K. Dwivedi, N. C. Piercy, and M. D. ${ }^{[49]}$ Williams, "M odeling Consumers' Adoption Intentions of Remote M obile Payments in the United

Kingdom : Extending UTAUT with Innovativeness, Risk, and Trust," Psychol. Mark., vol. 32, pp. 860873, 2015, doi: 10.1002/mar.20823.

[37] S. K. Sharma, "Integrating cognitive antecedents into TAM to explain mobile banking behavioral intention: A SEM -neural network modeling," Inf. Syst. Front., no. Zhou 2011, pp. 1-13, 2017, doi: 10.1007/s10796-[51] 017-9775-x.

[38] Suliyanto, "Uji Asumsi Klasik Normalitas," Ekon. Terap. Teor. Apl. dengan SPSS, p. 69, 2011.

[39] M . A. Oktaviani and H. B. Notobroto, "Perbandingan Tingkat Konsistensi Normalitas Distribusi M etode

Kolmogorov-Smirnov, Lilliefors, Shapiro-Wilk, dan Skewness-Kurtosis," J. Biometrika dan Kependud., vol. 3, no. 2, pp. 127-135, 2014.

[40] P. J. Jordan and A. C. Troth, "Common method bias in[53] applied settings: The dilemma of researching in organizations," Aust. J. Manag., no. August, 2019, doi: 10.1177/0312896219871976.

[41] A. Vishwanath, "Common M ethod Bias," Int. Encycl. Commun. Res. Methods, pp. 1-5, 2017, doi: 10.1002/9781118901731.iecrm0030.

[42] J. F. Hair, W. Black, B. Babin, and R. Anderson, [55] Multivariate Data Analysis, 8th ed. Boston, M A: Cengage Learning EM EA, 2018.

[43] T. P. Lim, F. Y. Chye, M . R. Sulaiman, N. M . Suki, and J. S. Lee, "A structural modeling on food safety knowledge, attitude, and behaviour among Bum Bum[56] Island community of Semporna, Sabah," Food Control, vol. 60 , pp. 241-246, 2016, doi:

10.1016/j.foodcont.2015.07.042.

[44] C. Cheng and H. Wu, "Confidence Intervals of Fit Indexes by Inverting a Bootstrap Test," Struct. Equ. Model., vol. 24, no. 6, pp. 870-880, 2017, doi: 10.1080/10705511.2017.1333432.

[45] J. C. Westland, "An introduction to structural equation models," Stud. Syst. Decis. Control, vol. 22, pp. 1-8, 2015, doi: 10.1007/978-3-319-16507-3_1.

[46] L. F. Rodrigues, A. Oliveira, and C. J. Costa, "Does ease-of-use contributes to the perception of enjoyment? A case of gamification in e-banking,"
Comput. Human Behav., vol. 61, pp. 114-126, 2016, doi: 10.1016/j.chb.2016.03.015.

S. T. Biucky, N. Abdolvand, and S. R. Harandi, "The effects of perceived risk on social commerce adoption based on the tam model," Int. J. Electron. Commer.

Stud., vol. 8, no. 2, pp. 173-196, 2017, doi:

10.7903/ijecs.1538.

S. Alkutbi, I. Alrajawy, M . Nusari, G. S. A. Khalifa, and A. E. Abuelhassan, "Impact of Ease of Use and Usefulness on the Driver Intention to Continue Using Car Navigation Systems in the United Arab Emirates," Int. J. Manag. Hum. Sci., vol. 3, no. 1, pp. 1-9, 2019.

M . Ali and S. A. Raza, "Service quality perception and customer satisfaction in Islamic banks of Pakistan: the modified SERVQUAL model," Total Qual. Manag. Bus. Excell., vol. 28, no. 5-6, pp. 559- 577, 2017, doi: 10.1080/14783363.2015.1100517.

[50] S. Djamasbi, a. L. Fruhling, and E. T. Loiacono, "The influence of affect, attitude and usefulness in the acceptance of telemedicine systems," J. Inf. Technol. Theory Appl., vol. 10, no. 1, pp. 41-58, 2009.

F. Gunawan, M . M . Ali, and A. Nugroho, "Analysis of the Effects of Perceived Ease of Use and Perceived Usefulness on Consumer Attitude and Their Impacts on Purchase Decision on PT Tokopedia In Jabodetabek," vol. 4, no. 5, pp. 1-6, 2019.

F. Aldhmour and I. Sarayrah, "Investigation of Factors Influencing Consumers , Intention to Use Online Shopping: An Empirical," J. Internet Bank. Commer., 2018.

M . M uchran, "Acceptance of Banking Information Technology in PT BNI of M akassar," vol. 7, no. 2, pp. 124-130, 2015.

[54] S. Gao and Y. Yang, "The role of trust towards the adoption of mobile services in china: An empirical study," IFIP Adv. Inf. Commun. Technol., vol. 445, pp. 46-57, 2014, doi: 10.1007/978-3-662-45526-5_5.

J. Zhao, S. Fang, and P. Jin, "M odeling and quantifying user acceptance of personalized business modes based on TAM , trust and attitude," Sustain., vol. 10, no. 2, pp. 1-26, 2018, doi: $10.3390 / \mathrm{su} 10020356$.

F. D. Davis, "Perceived usefulness, perceived ease of use, and user acceptance of information technology," MIS Q. Manag. Inf. Syst., vol. 13, no. 3, pp. 319-339, 1989, doi: $10.2307 / 249008$.

C. Hampshire, A mixed methods empirical exploration of UK consumer perceptions of trust, risk and usefulness of mobile payments, vol. 35, no. 3. 2017.

N. T. A. Zainal, A. Harun, and J. Lily, "Examining the mediating effect of attitude towards electronic words-of mouth (eWOM ) on the relation between the trust in eWOM source and intention to follow eWOM among M alaysian travellers," Asia Pacific Manag. Rev., vol. 22, no. 1, pp. 35-44, 2017, doi: 10.1016/j.apmrv.2016.10.0. 